\section{Recovery in People with Schizophrenia $(\mathrm{PwS})$}

\author{
Arum Septi Mawarni; Zainal Abidin; Ahmad \\ Gimmy Prathama Siswadi \\ Universitas Padjajaran \\ Jatinangor, Kabupaten Sumedang, 45363 \\ Email :arum16001@mail.unpad.ac.id
}

Journal PSIKODIMENSIA

Volume 18, No. 2,

Juni - Desember 2019

ISSN cetak : 1411-6073

ISSN online : $2579-6321$

DOI : 10.24167/psidim.v18i2.2242.

\begin{abstract}
The present study is aimed to find out the description of their recovery particularly those with residual type. This study was conducted in a mixed method using a descriptive design. Sample collection was conducted through purposive sampling, equipped with criteria of Residual Type PWS with age above 18 years old. Previously, testing of Recovery Assessment Scale (RAS) measuring instrument was conducted to $59 \mathrm{PWS}$, who were all outpatients. The result of this study reveals that using the method, PWS outpatients has a deemed high recovery rate, yet they still have constraints in dominant symptom factors.
\end{abstract}

Keywords: People With Schizophrenia (PWS), Recovery, Schizophrenia

\section{PENDAHULUAN}

Istilah skizofrenia (schizophrenia) merupakan kombinasi antara kata dalam bahasa Yunani untuk "split" (pecah) (skhizein) dan "mind" (pikiran) (phren), diperkenalkan oleh seorang psikiater Swiss yaitu Eugen Bleuler (1908) (Durand, \& Barlow, 2007). Orang dengan skizofrenia (ODS) menarik diri dari orang lain dan kenyataan, seringkali masuk ke dalam kehidupan fantasi yang penuh delusi dan halusinasi (Davison, Neale, \& Kring, 2012).

Berdasarkan data prevalensi badan kesehatan dunia (WHO), pasien skizofrenia di Indonesia sebesar satu persen atau diperkirakan ada sekitar 2,6 juta orang. Namun, angka ini bisa bertambah mengingat kebanyakan mereka yang mengalami skizofrenia adalah usia produktif. Berdasarkan hasil dari riset kesehatan dasar (Riskesdas) pada tahun 2018, didapati prevalensi gangguan jiwa berat (skizofrenia /psikosis) meningkat menjadi 7 per mil atau 7 orang dari 1000 orang. Hal ini meningkat dari data sebelumnya 1,2 per mil atau 1-2 orang dari 1000 orang warga di Indonesia (Riskesdas, 2013).

Pemahaman yang keliru terhadap gangguan skizofrenia memunculkan permasalahan berupa stigma dan diskriminasi. Adanya sebutan "orang gila", pengasingan dan pemasungan oleh keluarga atau masyarakat, keyakinan yang berkembang di masyarakat bahwa pemulihan Orang Dengan Skizofrenia (selanjutnya akan disebut ODS) sulit dicapai.

Pada zaman demonologi (150 SM), Orang yang mengalami gangguan mental diyakini dipengaruhi oleh kekuasaan roh jahat atau setan. Dewasa ini, sebagian keluarga dan masyarakat masih menganggap skizofrenia merupakan gangguan atau "penyakit" yang disebabkan oleh hal-hal yang tidak rasional ataupun supranatural. Sebagai contoh, ODS kerap dianggap sebagai "orang gila" yang disebabkan guna-guna atau diteluh, kemasukan setan, kemasukan roh jahat (evil spirit), melanggar larangan atau tabu dan lain jenisnya. Banyaknya ODS yang tidak 
dibawa ke dokter, melainkan dibawa ke dukun, "orang pintar", paranormal dan lain jenisnya. Dengan demikian, ODS bukan bertambah pulih melainkan bertambah parah (Hawari, 2014).

Disisi lain, pandangan itu tampak negatif dalam menggambarkan keadaan skizofrenia yang sebenarnya. Dengan usaha ODS disertai pengobatan medis ataupun terapi psikososial mampu memperbaiki keadaan. Meskipun ada faktor lain yang menghambat ODS untuk meningkatkan pemulihannya. Terkait bagaimana respon terhadap gejala, pengalaman efek samping obat, relaps, distress psikologi, penerimaan diri, kemampuan berinteraksi sosial, harapan, kebermaknaan, disosiasi kognitif, stigma, berfokus pada masalah dan lain sebagainya (dalam Dewi, 2015; Chadwick, 2014).

Pemulihan sendiri adalah sebuah pandangan baru untuk pelayanan kesehatan mental, dimana terdapat 2 macam definisi dari pemulihan. Pertama, pemulihan adalah sebuah hasil; penelitian menyarankan bahwa banyak orang dengan gangguan kejiwaan telah belajar untuk mengatasi ketidakmampuannya sehingga mereka bisa mencapai tujuan hidup yang berkaitan dengan hidup mandiri. Kedua, pemulihan adalah sebuah proses; memperkenalkan sebuah nilai-nilai yang penting seperti harapan, orientasi pada pemberdayaan dan tujuan didalam system pelayanan. Kedua definisi tersebut memiliki data yang mendukung, hal ini menunjukan bahwa integrasi keduanya menawarkan gambaran pemulihan yang paling lengkap dan efektif. Intervensi psikososial terintegrasi dengan strategi psikofarmakologis telah terbukti paling efektif membantuh individu untuk pulih (Corrigan, 2006).

Salah satu tujuan dari gerakan pemulihan yang muncul dari konsumen, penyintas, dan mantan pasien adalah meyuntikkan kembali harapan kedalam kehidupan orang yang terdiagnosis gangguan ini (Chamberlin, 1997; Deegan, 1988; Leeta, 1998, dalam Corrigan dan Phelan, 2004). Akibatnya, pemulihan dari perpektif ini kurang memperdulikan hasil-terkait apakah orang tersebut mencapai bebas dari gejala dan ketidakmampuan-dan lebih lenjut tentang proses. Daripada arti bebas dari gejala dan tanpa ketidakmampuan, pemulihan disini lebih berkaitan dengan kebermaknaan dalam hidup dan kenyamanan pribadi (Campbell \& Schraiber, 1989; Ralph, 2000, dalam Corrigan dan Phelan, 2004).

Pada penelitian ini hanya akan memfokuskan pada ODS dengan tipe residual. Tipe ini merupakan sisa-sisa (residu) dari gejala skizofrenia yang tidak begitu menonjol. Misalnya alam perasaan yang tumpul dan mendatar serta tidak serasi (inappropriate), penarikan diri dari pergaulan social, tingkah laku eksentrik, pikiran tidak logis dan tidak rasional atau pelonggaran asosiasi pikiran meskipun gejala-gejala skizofrenia tidak aktif atau tidak menampakkan gejala-gejala positif skizofrenia (Hawari, 2014).

Untuk itu sebelum sampai kepada intervensi yang tepat bagi ODS Ttpe Residual, peneliti ingin mengetahui bagaimana gambaran pemulihan pada ODS tipe Residual.

\section{METODE}

Metode yang digunakan dalam penelitian ini adalah metode deskriptif yang memberikan deskripsi mengenai subjek penelitian berdasarkan data dan variable yang diperoleh dan kelompok subjek yang diteliti dan tidak dimaksudkan untuk pengujian hipotesis (Azwar, 2012). Maka dari itu, penelitian ditujukan untuk melihat gambaran pemulihan pada ODS.

Pada penelitian ini variabel yang dilibatkan adalah Pemulihan pada Orang Dengan Skizofrenia (ODS). Teori yang 
mendasari variabel ini adalah teori dari Corrigan, dkk (1999) bahwa pemulihan merupakan sebuah proses (dalam, Corrigan dkk, 2004). Corrigan, dkk (2004) membagi faktor pemulihan menjadi 5; (1) kepercayaan diri dan harapan pribadi; (2) Tujuan dan Orientasi Kesuksesan;

Ketergantungan Positif pada Orang Lain; (4) Kesediaan untuk Meminta Bantuan; dan (5) Tidak didominasi oleh Gejala. Dengan instrument penelitian berupa Recovery Assesment Scale (RAS) yang awalnya terdiri dari 24 aitem.

Instrumen RAS diadaptasi dengan cara uji coba alat ukur, dari alat ukur asli RAS menurut Corrigan (2004). Kemudian dilakukan pengukuran reliabilitas dan validitas terhadap 59 ODS. Setelah melalui proses validitas dan reliabilitas terdapat 2 aitem yang gugur sehingga yang semula terdapat 24 aitem menjadi 22 aitem yang valid dan reliabel. Dengan reliabilitas 0.925 dan validitas $0.39<\mathrm{x}<0.749$.

Pengamblan sampel dari populasi dengan cara purposive sampling dengan inklusi kriteria diatas 18 tahun, terdiagnosa skizofrenia tipe residual oleh psikiater/psikolog, berada pada fase rawat jalan dalam pengobatannya, dan bersedia berpartisipasi dalam penelitian ini. Subjek penelitian berjumlah 4 ODS fase rawat jalan yang dipilih dari 59 ODS sebelumnya dan berdomisili di Bandung. Peneliti bekerja sama dengan instansi Grha Atma yang sebelumnya telat mendapatkan ijin etik dari RSJ Provinsi Jawa Barat.

\section{HASIL}

Berdasarkan hasil penelitian, didapatkan 59 partisipan dengan karakteristik demografi yang beragam. Responden dalam penelitian ini berada pada usia dewasa $83 \%$ dan dewasa awal 17\%. Responden ini terdiri dari $80 \%$ laki-laki dan $20 \%$ perempuan. Tingkat pendidikan responden umumnya SMA $39 \%$ dan Sarjana 25\% dan sisanya beragam. Berdasarkan status pekerjaan, Responden yang tidak memiliki pekerjaan sebanyak $44 \%$ dan yang memiliki pekerjaan sebanyak 56\%. Untuk diagnosis yang dimiliki oleh responden berkisar antara Skizofrenia Paranoid (36\%), Skizofrenia Residual (27\%), Skizofrenia (25\%), sisanya beragam diantara skizoafektif, skizofrenia hebefrenik, dan skizofrenia YTT. Hasil uji statistik deskriptif guna melihat sebaran demografik pada ODS yang berada di fase rawat jalan yang bisa dilihat pada Tabel 1 .

Tabel 1. Distribusi Data Karakteristik Demografi Responden Skizofrenia Rawat Jalan $(n=59)$

\begin{tabular}{lcc}
\hline Karakteristik Demografi & n & \% \\
\hline Umur & & \\
\hline Dewasa awal (18-25 Thn) & 10 & $17 \%$ \\
\hline Dewasa (25-65 Thn) & 49 & $83 \%$ \\
\hline Jenis Kelamin & & \\
\hline Laki-laki & 47 & $80 \%$ \\
\hline Perempuan & 12 & $20 \%$ \\
\hline Tingkat Pendidikan & & \\
\hline Tidak Sekolah & 0 & $0 \%$ \\
\hline SD & 8 & $14 \%$ \\
\hline SMP & 8 & $14 \%$ \\
\hline SMA & 23 & $39 \%$ \\
\hline Vokasi & 5 & $8 \%$ \\
\hline Sarjana & 15 & $25 \%$ \\
\hline Pekjaan
\end{tabular}

Pekerjaan

\begin{tabular}{lcc}
\hline Tidak ada & 26 & $44 \%$ \\
\hline Ada & 33 & $56 \%$ \\
\hline Diagnosis & $\mathrm{n}$ & $\%$ \\
\hline Skizofrenia & 15 & $25 \%$ \\
\hline Skizofrenia Paranoid & 21 & $36 \%$ \\
\hline Skizofrenia Residual & 16 & $27 \%$ \\
\hline Skizoafektif & 3 & $5 \%$ \\
\hline Skizofrenia Hebefrenik & 3 & $5 \%$ \\
\hline Skizofrenia YTT & 1 & $2 \%$ \\
\hline
\end{tabular}

Dalam deskripsi data
memungkinkan peneliti untuk
melakukan kategorisasi dengan mengacu
pada kriteria 3 kelompok oleh Azwar
(2012), yaitu rendah, sedang, dan tinggi.
Tujuan dari kategorisasi ini untuk
menempatkan subjek ke dalam
kelompok-kelompok yang posisinya
berjenjang menurut suatu norma
kategori yang telah ada dan agar data


akan lebih mudah di pahami (Azwar, 2012).

Tabel 2. Kategorisasi pemulihan ODS fase rawat jalan

\begin{tabular}{ccc}
\hline Kategori & Rentang & Jumlah ODS \\
\hline Rendah & $0-36$ & 0 \\
Sedang & $37-73$ & 3 \\
Tinggi & $74-110$ & 56 \\
\hline
\end{tabular}

Berdasarkan hasil data tabel 2, variabel pemulihan dari 59 responden memiliki nilai rata-rata 87.36 dan berada pada kategori Tinggi. Untuk nilai minimum (46) berada pada kategori sedang, dan untuk nilai maksimum (110) berada pada kategori tinggi.

Berdasarkan hasil penelitian terdapat karakteristik pemulihan dari ODS yang diklasifikasikan menjadi 5 faktor sesuai dengan Corrigan (2004). Hasilnya didapat bahwa kategori pemulihan ODS fase rawat jalan berada di kategori tinggi (95\%) dan Sedang (5\%). Dapat dilihat di tabel 3.

Tabel 3. Karakteristik Pemulihan Responden Skizofrenia Rawat Jalan ( $\mathrm{n}=59)$

\begin{tabular}{|c|c|c|}
\hline Karakteristik Pemulihan & $\mathbf{n}$ & $\%$ \\
\hline \multicolumn{3}{|l|}{ Kepercayaan diri dan harapan pribadi } \\
\hline Rendah & 1 & $2 \%$ \\
\hline Sedang & 9 & $15 \%$ \\
\hline Tinggi & 49 & $83 \%$ \\
\hline \multicolumn{3}{|l|}{ Tujuan dan Orientasi Kesuksesan } \\
\hline Rendah & 1 & $2 \%$ \\
\hline Sedang & 1 & $2 \%$ \\
\hline Tinggi & 57 & $96 \%$ \\
\hline \multicolumn{3}{|l|}{ Ketergantungan positif pada orang Lain } \\
\hline Rendah & 0 & $0 \%$ \\
\hline Sedang & 15 & $25 \%$ \\
\hline Tinggi & 44 & $75 \%$ \\
\hline \multicolumn{3}{|l|}{ Kesediaan untuk meminta bantuan } \\
\hline Rendah & 1 & $2 \%$ \\
\hline Sedang & 6 & $10 \%$ \\
\hline Tinggi & 52 & $88 \%$ \\
\hline \multicolumn{3}{|l|}{ Tidak didominasi oleh gejala } \\
\hline Rendah & 1 & $2 \%$ \\
\hline Sedang & 27 & $46 \%$ \\
\hline Tinggi & 31 & $52 \%$ \\
\hline \multicolumn{3}{|l|}{ Pemulihan } \\
\hline Rendah & 0 & $0 \%$ \\
\hline Sedang & 3 & $5 \%$ \\
\hline Tinggi & 56 & $95 \%$ \\
\hline
\end{tabular}

Setelah analisis deskripsi dari ke-59 partisipan, kemudian 4 partisipan yang terdiagnosis skizofrenia residual bersedia untuk dilakukan wawancara 
secara kualitatif. Berikut gambaran identitas ODS tipe residual, yang dilakukan wawancara dengan mengacu pada faktor-faktor pemulihan.

Tabel 4. ODS Tipe Residual Fase Rawat Jalan

\begin{tabular}{lcccc}
\hline \multicolumn{1}{c}{ Inisial } & P1 (BD) & P2 (DR) & P3 (FS) & P4 (R) \\
\hline Usia & 40 thn & 39 thn & 37 thn & 42 thn \\
JK & Lk & Lk & Lk & Lk \\
Suku & Sunda & Sunda & Sunda & Sunda \\
Agama & Islam & Islam & Islam & Islam \\
Pendidikan & SMA & SMK & S1 & SMA \\
Pekerjaan & Pedagang & Penyedia jasa & Penjaga kosan & Tidak bekerja \\
Status & Menikah & Duda & Belum menikah & Belum menikah \\
Anak-ke & 1 dari 4 & 2 dari 3 & 5 dari 5 & 1 dari 4 \\
Tinggal dengan & Istri dan anak & Orang tua dan anak & Ibu dan kakak & Ibu dan adik \\
Diagnosis & SR & SR & SR & SR \\
Onset & \pm 20 tahun & 18 tahun & 16 tahun & 24 tahun \\
Riwayat Keluarga & Nenek & Tidak ada & Kakak & Paman \\
\hline
\end{tabular}

Berdasarkan tabel 4 diatas, terdapat persamaan dan perbedaan yang menjadi ciri khas dari setiap partisipan. Persamaan yang ditemukan dari keempat partisipan ialah seluruh partisipan merupakan ODS tipe residual yang berjenis kelamin laki-laki, berusia diantara 37-42 tahun, dengan latar belakang pendidikan minimal SMA, bersuku bangsa Sunda, beragama Islam, berdomisili di Bandung, dan status ekonomi menengah kebawah. Perbedaan yang terdapat antara partisipan yaitu perbedaan status pernikahan, usia onset, pekerjaan, susunan anak ke- dan riwayat sakit keluarga.

Ke-4 partisipan memiliki nilai pemulihan yang berada di rentang tinggi, berikut tabel 5 yang menggambarkan hasil pemulihan dari ke-4 partisipan.

Tabel 5. Pemulihan ODS Tipe Residual

\begin{tabular}{ccc}
\multirow{2}{*}{ Partisipan } & \multicolumn{2}{c}{ Pemulihan } \\
\cline { 2 - 3 } & Nilai & Kategori \\
\hline P1 & 98 & Tinggi \\
P2 & 103 & Tinggi \\
P3 & 99 & Tinggi \\
P4 & 100 & Tinggi \\
\hline
\end{tabular}

\section{Partisipan 1 (BD)}

P1 merupakan anak pertama dari 4 bersaudara. Ia tinggal bersama istri dan 1 orang anaknya. Dari segi penampilan P1 tampak cukup sederhana dalam mengenakan pakaian, ia sering mengenakan topi dalam berpergian. Terkait kondisi fisik, P1 memiliki kesulitan dalam berjalan dikarenakan dulu (usia 20an) ia mengalami kecelakaan yang menyebabkan kakinya mengalami patah tulang, sehingga dalam berjalan dan gerakan lain yang membutuhkan bantuan kaki, P1 tampak kesulitan. Terkait kondisi psikis, P1 tampak sering menatap sesuatu hal dengan tatapan kosong (melamun). Dikarenakan lamunan tersebut, P1 merasa masih sering mendengar suarasuara yang ada didalam pikirannya dalam bentuk obrolan tidak jelas.

P1 tidak mengingat dengan jelas apa riwayat awal yang menyebabkan ia mengalami gangguan skizofrenia. Sejak remaja, P1 merasa dirinya adalah orang yang tertutup dan sering melamun. Saat berusia 20an, P1 yang belum mendapatkan pekerjaan merasa stres, sehingga hal tersebut membuatnya sering marah-marah dan melamun tidak jelas, bahkan mendengar suara-suara. Ia kemudian berobat di cisarua dan mengalami perbaikan. Meskipun memiliki sakit gangguan jiwa, P1 merasa senang ada wanita yang mau menikah dengannya. Setelah menikah, P1 juga mengalami stres kembali dikarenakan mendapat PHK dari 
perusahaan Telkom, ia dulu bekerja di bagian manajemen. Dikarenakan menganggur timbul kembali perilaku yang sering melamun, dan mendengar suara-suara orang lain berbincang. Saat itu P1 merasa tertekan dikarenakan perannya sebagai ayah dan suami tidak bisa berjalan dengan baik. Ia tidak bisa menafkahi istri dan anaknya. Dikarenakan muncul kembali halusinasi suara dan perilaku yang mengamuk, P1 dibawa ke RS.Cisarua dan hingga kini berobat jalan di Grha Atma, Bandung.

Tabel 6. Faktor-faktor Pemulihan ODS Tipe Residual

\begin{tabular}{|c|c|c|}
\hline Partisipan & Faktor faktor & $\begin{array}{c}\text { Pemulihan } \\
\text { (Kategori) }\end{array}$ \\
\hline \multirow[t]{10}{*}{ P1 } & \multirow[t]{2}{*}{ Kepercayaan Diri dan Harapan Pribadi } & 34 \\
\hline & & $(\mathrm{T})$ \\
\hline & \multirow[t]{2}{*}{ Tujuan dan Orientasi Masa Depan } & 22 \\
\hline & & $(\mathrm{T})$ \\
\hline & \multirow[t]{2}{*}{ Ketergantungan (+) Pada Orang Lain } & 20 \\
\hline & & $(\mathrm{T})$ \\
\hline & \multirow[t]{2}{*}{ Kesediaan untuk Meminta Bantuan } & 12 \\
\hline & & $(\mathrm{T})$ \\
\hline & \multirow[t]{2}{*}{ Tidak Didominasi Gejala } & 10 \\
\hline & & $(\mathrm{T})$ \\
\hline \multirow[t]{10}{*}{$\mathrm{P} 2$} & \multirow[t]{2}{*}{ Kepercayaan Diri dan Harapan Pribadi } & 36 \\
\hline & & $(\mathrm{T})$ \\
\hline & \multirow[t]{2}{*}{ Tujuan dan Orientasi Masa Depan } & 25 \\
\hline & & $(\mathrm{T})$ \\
\hline & \multirow[t]{2}{*}{ Ketergantungan (+) Pada Orang Lain } & 18 \\
\hline & & $(\mathrm{T})$ \\
\hline & \multirow[t]{2}{*}{ Kesediaan untuk Meminta Bantuan } & 15 \\
\hline & & $(\mathrm{T})$ \\
\hline & \multirow[t]{2}{*}{ Tidak Didominasi Gejala } & 9 \\
\hline & & $(\mathrm{T})$ \\
\hline \multirow[t]{10}{*}{ P3 } & \multirow[t]{2}{*}{ Kepercayaan Diri dan Harapan Pribadi } & 35 \\
\hline & & $(\mathrm{T})$ \\
\hline & \multirow[t]{2}{*}{ Tujuan dan Orientasi Masa Depan } & 25 \\
\hline & & $(\mathrm{T})$ \\
\hline & \multirow[t]{2}{*}{ Ketergantungan (+) Pada Orang Lain } & 20 \\
\hline & & $(\mathrm{T})$ \\
\hline & \multirow[t]{2}{*}{ Kesediaan untuk Meminta Bantuan } & 12 \\
\hline & & $(\mathrm{T})$ \\
\hline & \multirow[t]{2}{*}{ Tidak Didominasi Gejala } & 8 \\
\hline & & (T) \\
\hline \multirow[t]{9}{*}{ P4 } & \multirow[t]{2}{*}{ Kepercayaan Diri dan Harapan Pribadi } & 35 \\
\hline & & $(\mathrm{T})$ \\
\hline & \multirow[t]{2}{*}{ Tujuan dan Orientasi Masa Depan } & 25 \\
\hline & & $(\mathrm{T})$ \\
\hline & \multirow[t]{2}{*}{ Ketergantungan (+) Pada Orang Lain } & 20 \\
\hline & & $(\mathrm{T})$ \\
\hline & \multirow[t]{2}{*}{ Kesediaan untuk Meminta Bantuan } & 12 \\
\hline & & $(\mathrm{T})$ \\
\hline & Tidak Didominasi Gejala & 8 \\
\hline
\end{tabular}

Saat ini, P1 merasa keadaannya semakin membaik dibandingkan dulu. Dukungan istri, anak, bahkan tetangga yang dahulu membantunya saat sakit membuatnya merasa yakin keadaannya bisa sembuh. Meskipun mulai 
mengalami perbaikan keadaan, terkait emosi yang lebih terkendali, dan suarasuara yang dulu menghakimi P1 semakin jarang, dan lebih terdengar suara-suara yang tidak jelas pembicaraannya. Dahulu ia setiap hari mendengar dan bisa dalam waktu lama. Saat ini ia akan mendengar suara tidak jelas seminggu 4 kali, akan lebih sering jika melamun, dan dalam waktu 10 menit. Dikarenakan mengonsumsi obatobatan psikotik, P1 merasa mendapatkan efek samping berupa tangan atau kakinya yang sering bergetar, Berat badannya meningkat (dikarenakan kegiatannya hanya makan dan tidur), dan ia merasa kurang bertenaga dan lebih memilih untuk sering beristirahat (tidur).

Terkait faktor-faktor pemulihan dalam hal kepercayaan diri dan harapan pribadinya, P1 merasa masih memiliki harapan untuk bisa sembuh $100 \%$, bisa bekerja, dan tidak meminum obat-obatan antipsikotik lagi. Hal itu juga menjadi tujuannya saat ini. Dalam keseharian P1 memiliki ketergantunga positif dengan orang lain, seperti keluarga inti dan tetangga. Ia merasa stigma negatif tidak datang dari keluarga inti dan tetangga, tetapi justru dari masyarakat luas yang tidak terlalu mengenal dirinya. Disaat yang membutuhkan, P1 juga memiliki kesediaan untuk meminta bantuan kepada keluarga khususnya. Berkaitan dengan dominasi gejala, seperti yang dijelaskan sebelumnya ia masih cukup didominasi oleh gejala positif berupa halusinasi suara. Sehingga secara keseluruhan P1 merasa masih belum pulih, bahkan merasa di rentang 60-65 terkait keadaannya saat ini.

\section{Partisipan 2 (DR)}

P2 merupakan anak ke-2 dari 3 bersaudara. Ia tinggal di rumah bersama ibu, adik tiri, dan ayah tirinya. Ayah kandung P2 tinggal di cianjur, tetapi sering beberapa kali datang kerumah dikarenakan mengalami sakit stroke dan berobat di RSHS. P1 lah yang bertugas untuk mengantarkan ayah kandungnya berobat ke RSHS. P1 memiliki status duda, ia menceraikan istrinya 5 tahun setelah pernikahan dengan alasan tidak ingin menyakiti istrinya terkait keadaan gangguan skizofrenia yang ia miliki. Dari segi penampilan, $\mathrm{S}$ tampak rapih dan sopan serta mengenakan jaket. Cara berjalan P2 tampak lamban, dengan menundukan kepalanya (minim kontak mata) dan tampak sedikit membungkuk. Terkait kondisi fisik, P2 mengatakan ia memiliki sakit maag dan sering merasa lemas. Hal tersebut membuatnya sering tidur dari setelah maghrib tetapi terbangun di jam 10 atau 11. Setelah itu ia akan terjaga hingga subuh. Terkait kondisi psikisnya, P2 menyampaikan kesulitan untuk bisa fokus ketika berbicara dengan orang lain.

Terkait riwayat gangguannya, P2 mengingat sekitar usia 18 tahun ia bekerja ke Malaysia. Kemudian merasa tidak betah untuk bekerja disana karena tuntutan kerja yang sangat tinggi dan membuat P2 keletihan berlebih. Hal tersebut, membuat P2 memberanikan diri kabur kembali ke Indonesia. Setelah di rumah P2 merasa sering marah-marah dan juga mengamuk-ngamuk dengan melempar barang. P2 mengalami pengobatan secara tradisional, pengobatan itu berupa penyiraman dan penenggalaman kepala P2 ke kolam air. Setelah itu ia kabur dari pengobatan, dan kemudian melanjutkan pengobatan ke RSHS dan RS.Cisarua. Setelah mulai keadaan membaik P2 memutuskan menikah dengan wanita di tahun 2005 dan memiliki 1 orang anak. Dikarenakan kesulitan masalah pekerjaan, P2 kembali sulit mengendalikan emosinya dan sering berteriak marah-marah kepada istrinya. Kemudian P2 meminta istrinya untuk menceraikannya, dengan alasan ia tidak tega jika kekambuhan sakitnya dengan marah-marah malah menyakiti istrinya. Setalah 5 tahun menjalin rumah 
tangga $\mathrm{S}$ kemudian bercerai dengan istrinya, dan saat ini istrinya telah menikah kembali dengan orang lain. P2 memahami sakitnya dahulu dikarenakan emosi yang meledak-ledak dan tidak bisa dikendalikan.

Saat ini P2 merasa keadaannya membaik dibandingkan sebelumnya. Ia sudah bisa untuk melaksanakan aktivitas sendiri seperti melakukan reparasi radio, membantu ibu dalam pekerjaan rumah, dan mengantar anak ke sekolah. Meskipun ia merasa di malam hari seringkali sulit untuk jatuh tertidur dengan lelap. Ia seringkali terbangun di tengah malam dan sulit tidur kembali. Ia juga merasa semakin meningkat berat badannya. Disamping itu, seringkali adanya keluhan fisik seperti pusing, flu, dan juga demam. Terkait gejala dari gangguannya, P2 masih mendengar suara orang mengobrol yang tidak jelas.

Terkait faktor-faktor pemulihan, dalam hal kepercayaan diri dan harapan pribadi ia masih merasa sebagai orang yang tidak percaya diri dan memiliki harapan terkait kesehatannya agar semakin membaik. Tujuan P2 saat ini adalah untuk menemukan peluangpeluang usaha agar tidak menyusahkan kedua orang tuanya. P2 merasa memiliki ketergantungan yang positif dengan keluarga inti, meskipun dengan orang lain ia merasa biasa saja dan cenderung tidak dekat. Kesediaan meminta bantuan biasanya akan muncul ketika P2 sudah merasa tidak mampu lagi mengatasinya, khususnya saat ia kambuh. Terkait gejala yang mendominasi, seperti yang sudah disampaikan sebelumnya ia masih memiliki gejala positif berupa halusinasi suara dan membatasi diri dari lingkungan sekitar. Jika hal tersebut muncul akan P2 atasi dengan minum obat dan tidur. Secara keseluruhan P2 merasa bahwa ia sudah mengalami perbaikan kondisi terkait pemulihannya, meskipun masih merasa adanya simtom negative (menjaga jarak dengan sekitar karena cemas dan merasa minder). P2 merasa bahwa presentasi pemulihannya berada di $70 \%$.

\section{Partisipan 3 (FS)}

P3 merupakan anak ke5 dari 5 bersaudara. Ia tinggal bersama dengan ibu dan kakaknya. Kegiatan sehari-hari P3 adalah menjaga kos-kosan yang ada dirumahnya. Dari segi penampilan, P3 tampak rapih dan bersih. Cara berjalannya tampak lambat, dan cara berbicaranya tampak terbata-bata (dari kecil). Terkait kondisi fisiknya, P3 mengatakan memiliki penyakit GERD yang mengakibatkan tenggorokannya terasa kering dan tidak nyaman untuk menelan makanan. Terkait kondisi psikisnya, P3 merasa takut dan tidak percaya diri ketika berinteraksi dengan orang lain.

Terkait riwayat gangguannya, P3 memahami gangguannya merupakan bentuk depresi dikarenakan perilaku bullying yang ia dapatkan sejak remaja. P3 juga mengatakan adanya kakak yang dirawat di rumah sakit dikarenakan stress yang berlebih yang P3 kurang pahami penyebabnya. P3 merasa terjadi perubahan pada dirinya saat SMA di usia 16 tahun. Ia merasa mengalami perasaan tidak percaya diri dikarenakan memiliki tubuh yang kecil dan kurus. Dikarenakan hal tersebut ia juga mendapatkan bullyan verbal dari temantemannya. P3 sering mengurung diri dikamar, bahkan sellau merasa ada yang mengikutinya dimanapaun P3 pergi. Hal ini membuat P3 memilih untuk tidak masuk sekolah dikarenakan khawatir ada yang mengikutinya secara terus menerus. P3 kemudian berobat ke RSHS. Saat masuk kuliah, P3 merasa semakin sulit untuk bisa menjalin relasi dengan sesama jenis ataupun lawan jenis. Saat masuk kuliah, permasalahan untuk menjalin relasi kembali lagi terjadi, P3 juga merasa jurusan perkuliahan yang ia ambil tidak sesuai dengan dirinya. Hal ini yang membuat P3 memutuskan keluar dari 
universitasnya dan pindah ke universitas lain dengan jalur D3.

Saat ini, P3 merasa keadaannya sudah semakin membaik. Meskipun banyak ketakutan pada dirinya namun semakin kesini keadaannya semakin membaik. P3 yang dulu takut untuk berpergian sendiri, sekarang telah mampu meskipun ada beberapa tempat yang ia takuti dan ia hindari (memilih jalan memutar), P3 yang dulu merasa takut untuk naik angkot (seringkali kepalanya bergoyang terus menerus dan sulit ia hindari).

Terkait faktor-faktor pemulihan, P3 merasa memiliki kepercayaan diri yang rendah khususnya dalam hal berkomunikasi. Untuk itu ia memiliki harapan agar mampu berkomunikasi dengan baik agar semakin meningkat kepercayaan dirinya. P3 memiliki tujuan dan orientasi masa depan untuk menikah. Ia juga memiliki ketergantungan positif pada orang lain khususnya pada ibu dan kaka, bahkan seringkali ketergantungan itu amat berlebihan sehingga membuat P3 bahkan sering mengambil keputusan berdasarkan saran ibu atau kakanya. Hal ini semakin membuatnya memiliki kesediaan yang sangat tinggi dalam hal meminta bantuan khususnya berkaitan dengan tugas sehari-hari. Terkait gejala yang mendominasi, selain menghindari situasi social tertentu (khawatir berlebih pembicaraan orang lain tentangnya), P3 juga masih memiliki halusinasi dengaar orang-orang yang membicarakannya. Hal tersebut hanya P3 atasi dengan mendiamkannya, meminum obat dan tidur. Secara keseluruhan, P3 merasa mengalami pemulihan berupa perbaikan kondisi dengan sudah mampu pergi sendiri ke beberapa tempat. Tetapi pulih sembuh seutuhnya masih dirasa belum oleh P3, diakrenakan masih adanya rasa takut dibicarakan orang dan halusinasi dengar. Maka presentase pemulihan menurut $\mathrm{P} 3$ sebesar $70 \%$.

\section{Partisipan 4 (R)}

P4 merupakan anak ke-1 dari 4 bersaudara. Ia tinggal bersama ibu dan dua adiknya. Penampilannya tampak berantakan dan memiliki bau yang tidak mengenakan. Kegiatan sehari-hari P4 adalah hanya duduk diam menjaga toko bangunan milik pamannya. Terkait kondisi fisiknya, P4 memiliki asam urat yang beberapa kali kambuh. Terkait kondisi psikisnya, P4 sering merasa bingung dan kesulitan dalam menyampaikan sesuatu yang ada didalam pikirannya. Ia merasa hal yang ingin ia sampaikan tiba-tiba menghilang didalam pikirannya.

Berdasarkan riwayat keluarga, Paman (adik dari ibu) memiliki gangguan skizofrenia dan pernah di rawat di rumah sakit. P4 tidak terlalu ingat betul awal mula ia sakit, tetapi yang diingat adalah saat $\mathrm{P} 4$ jatuh dari mobil dan kepalanya terbentur. Ia merasa masih terus dibayangi gambar atau potret masa lalu terkait kebersamaannya dengan saudarasaudara di Cirebon. Ia menginginkan hal itu terjadi dan merasa rindu dengan saudara-saudaranya tersebut.

Keadaan P4 saat ini, ia merasa masih merasa bingung dan tidak tau berbuat apa. P4 masih sering mendengar halusinasi suara-suara yang beragam tidak ia kenali, ia juga merasa bisa berkirim pesan melalui pikiran dengan saudara-saudaranya, serta melihat adanya potret seperti film yang bergerak (ketika P4 melamun). Terkait hubungan social, P4 hanya sebatas menjalin komunikasi dengan keluarga inti dan paman.

Terkait faktor-faktor pemulihan, dalam hal kepercayaan diri dan harapan pribadi, P4 masih merasa memiliki keraguan meskipun masih ada harapan untuk sembuh. Tujuan dan orientasi masa depannya masih saja berkutat pada keinginan untuk bertemu dengan saudara yang ada di Cirebon dikarenakan rasa rindu yang ada didalam 
hatinya. Dikarenakan tinggal dengan ibu, meskipun kurang begitu dekat dan jarang berkomunikasi, P4 masih merasa adanya ketergantungan positif dengan ibu. Namun, ia jarang meminta bantuan dengan ibu dan adiknya kecuali jika keadaan terdesak seperti meminta uang. Terkait dominasi gejala, selain halusinasi visual yang disebutkan sebelumnya, P4 juga masih mendengar halusinasi suara, meskipun keadaan emosinya yang sering marah-marah berangsur-angsur berkurang intensitasnya. Secara keseluruhan, P4 merasa masih belum pulih dan berada di presentasi $60 \%$.

\section{DISKUSI}

Temuan dari penelitian ini adalah 1) dari ke-59 ODS rawat jalan memiliki skor RAS dengan kategorisasi tinggi sebanyak 95\%, hal ini berarti para partisipan memberikan penilaian terkait pemulihannya sudah berada di rentang tinggi. 2) setelah dilakukan pengambilan sample untuk ODS tipe residual sebanyak 4 partisipan ditemukan adanya kesamaan rentang usia, agama, suku, status sosial ekonomi. Keempat partisipan memiliki kategorisasi tinggi pada ke-5 faktor RAS. Hal ini menunjukan keempat partisipan merasa mengalami pemulihan dalam hal kepercayaan diri dan harapan pribadi, tujuan dan orientasi kesuksesan, kesediaan meminta bantuan, ketergantungan positif pada orang lain, dan tidak didominasi oleh gejala 3) Hasil wawancara yang didapat pada keempat partisipan menunjukan penilaian yang lebih rendah terkait pemulihan. Dimana semua partisipan merasa belum pulih. Hal ini mungkin berkaitan dengan butir soal yang sifatnya favourable yang membuat partisipan menjawab secara stereotype(4) Keadaan terparah secara gejala positif dimiliki oleh P4, namun hasil RAS menunjukan skor terendah pada P1. Hal ini memberikan data tambahan terkait bagaimana para partisipan memandang pemulihannya. Dukungan sosial juga tampak menjadi hal yang penting bagi pemulihan ODS khusunya bagi P1 yang bahkan mendapatkan dukungan sosial dari lingkungan sekitar. 5) Dengan keadaan ODS yang semakin membaik dalam hal gejala positif (meskipun masih memilikinya) namun tampak para ODS memiliki hambatan dalam lingkungan sosial sehingga dibutuhkan suatu bentuk terapi yang mampu mensasar recovery secara keseluruhan pada ODS tipe residual, sehingga mereka lebih mampu hidup penuh dan mandiri.

\section{SIMPULAN}

Berdasarkan analisis deskriptif, secara kuantitaif dan kualitatif dapat disimpulkan bahwa:

Hasil analisis deskriptif kuantitatif untuk pemulihan dalam kategori tinggi sebesar 95\% dari 59 ODS. Hal ini memberikan gambaran positif bahwa sebagian besar ODS yang berada di fase rawat jalan ternyata mampu mencapai pemulihan.

Ke-4 ODS tipe residual pun memiliki kategori pemulihan yang tinggi. Namun hal ini tampak tidak didukung oleh data kualitatif hasil wawancara yang menunjukan pemulihan yang masih rendah khususnya untuk faktor-faktor tertentu. Masih didapatinya kendala-kendala pada ODS khususnya pada faktor kepercayaan diri dan harapan pribadi, tujuan hidup dan orientasi masa depan, serta Tidak didominasi gejala.

Bagi ke-4 ODS tipe residual, faktor tidak didominasi gejala yang memiliki kategorisasi tinggi, namun tampaknya masih menjadi kendala besar dikarenakan masih memiliki simtom positif dan simtom negative, disertai kurangnya alternative solusi untuk mengatasi gangguan (mendiamkan, tidur, dan meminum obat). 
Berdasarkan kategorisasi yang didapatkan dari setiap faktor dari ke-59 ODS. Hal yang tampak masih menjadi fokus penting bagi ODS fase rawat jalan terkait dominasi gejala. Masih cukup besarnya kategori sedang (46\%) dan adanya kategori rendah (2\%) menandakan bahwa ODS fase rawat jalan masih terus berfokus pada bagaimana mengatasi gejala yang muncul. Sehingga tampaknya dibutuhkan intervensi atau program yang mampu melatih ODS untuk bisa mengatasi dominasi dari gejala skizofrenia.

Berdasarkan data demografi dari ke-59 ODS, didapatkan bahwa laki-laki usia dewasa tampak lebih banyak yang mendapatkan diagnosis skizofrenia dan berada pada fase rawat jalan. Selain itu presentase antara status bekerja dan tidak bekerja tampak hampir sebanding dimiliki oleh responden (ODS fase rawat jalan). Hal ini pun bisa menjadi gambaran terkait di usia yang masih produktif tampak ODS memiliki masalah pekerjaan (mendapatkan pekerjaan). Hal ini tampak perlu untuk diteliti kembali.

Penelitian selanjutnya diharapkan dapat memberikan suatu bentuk terapi ataupun program yang berfokus pada pemulihan ODS khususnya berkaitan dengan penanganan gejala-gejala dari gangguan agar semakin meningkatkan keberfungsian hidupnya.

\section{DAFTAR PUSTAKA}

Azwar, S. (2012). Metode penelitian. Yogyakarta: Pustaka Pelajar.

Chadwick, P. (2014). Mindfulness for Psychosis. The British Journal of Psyvhiatry.

Corrigan, P. W. (2006). Recovery from schizophrenia and the role of evidence-based psychosocial interventions. Expert Rev.Neurotherapeutics 6(7), 9931004. www.future-drugs.com

Corrigan, P.W., and Phelan, S.M. (2004). Social Support and Recovery in People with Serious Mental Illness. Community Mental Health Journal. 40(6): 513-523. Diakses pada tanggal 19 Maret 2018 dari http://www.search.ebscohost.com

Corrigan, P.W., Salzer, W., Ralph, R.O., Sangster, Y., \& Keck, L. (2004). Examining the Factor Structure of the Recovery Assessment Scale. Schizophrenia Bulletin. Vol.30, No.4. Diakses pada tanggal 12 Juni 2018 dari https://watermark.silverch.

Davison, G. C., Neale, J.M., \& Kring, A.M. (2012). Psikologi Abnormal (ed 9) (Noermalasari Fajar, Penerjemah). Depok: Rajagrafindo Persada.

Depkes RI. 2018. Riset Kesehatan Dasar. Jakarta: Badan Penelitian dan Pengembangan Kesehatan Kementrian Kesehatan RI.

Depkes RI. 2013. Riset Kesehatan Dasar. Jakarta: Badan Penelitian dan Pengembangan Kesehatan Kementrian Kesehatan RI. 
Dewi, E.C. (2015). Remisi dan Rekoveri Penderita Skizofrenia. Surabaya: FK UNAIR/RSUD Dr. SOETOMO

Durand, V. M., \& Barlow, D. H. (2007). Psikologi Abnormal (ed 4). Jakarta: Pustaka Pelajar.

Hawari, D. (2014). Skizofrenia: Pendekatan Holistik (BPSS) BioPsiko-Sosial-Spiritual. Jakarta: FKUI.

WHO. (2019, 17 April). Mental health: Schizophrenia. Diakses dari https://www.who.int/mental_healt $\mathrm{h} /$ management/schizophrenia/en/ 